\title{
A study on Determinants of Turnover Intention In
}

\section{Pakistan}

\author{
Asma Bashir \\ Research Scholar, Department of Management Sciences \\ The Islamia University of Bahawalpur, Pakistan \\ Email: Asma6720@yahoo.com \\ Faiza Durrani \\ Research Scholar, Department of Management Sciences \\ The Islamia University of Bahawalpur, Pakistan \\ Email: Faiza7782@yahoo.com
}

Accepted: September 22, 2014

Doi:10.5296/ jpag.v4i3.6681 URL: http://dx.doi.org/10.5296/ jpag.v4i3.6681

\begin{abstract}
Today's turnover intention is very challenging for any organization. Organizations should proper plan to recover this issue. The aims of this study were to examine the relationship between turnover intention and job satisfaction particularly the relationship of important factors i.e. job stress job commitment and organizational commitment on job satisfaction and on the other hand their relationship between turnover intention. A sample of 150 employees in the number of organization was used. In this study survey questioner was used the reliability and regression analysis was used to test hypothesis with the help of spss. The result shows that job commitment is an important variable toward job satisfaction and On the other hand job stress is an important variable which affect turnover intention. Limitations and future research suggestions are discussed.
\end{abstract}

Keywords: Turnover intention, Job stress, Organization Commitment, Job Commitment, Job Satisfaction 


\section{Introduction}

In the face of globalization \& world force diversity, it is critical for organizations to maintain their best employee as they are facing many challenges with the growing combination of the world economy into single, huge market place ensuring strong global competition. (Chandrashekharan, 2006). Turnover is not only costly but also has negative organizational implications. In Malaysia the average employee turnover rate is $18 \%$.Organizations have to bear high costs of recruiting, hiring, training, \& getting new employee up to speed due to employee turnover. The factors that influence turnover intension are job commitment, job stress, organizational commitment, job satisfaction employee turnover and consequences of worker turnover.

Shaw et al., (1998) show that Turnover intention is an intensely studied event. One recent meta-analysis by Griffeth and Hom, (1995) analysis over 800 such studies (Iverson, 1999). There is no accurate clarification for why people want to leave an organization (Mitchell and Lee, 1994).Turnover can be classify as involuntary or voluntary, functional or dysfunctional (Watrous et al., 2006). The types of turnover have influence negatively on the organization. Intentionally or voluntary organizational turnover is a process in which an individual makes a choice to stay or leave the organization (McPherson, 1976). Dysfunctional turnover and can be harmful to the organization (Mobley, 1982).

Hollman and Abbasi (2000) notify that the employees who are excessively more likely to leave. When these employees decide to leave organizations, their knowledge, experience also leave with them which results in efficiency delays cause by their vacancy (Hollman and Abbasi, 2000), which causes organizational dysfunction. On the other hand, involuntary turnover is a process in which the organization supposes be in command of on the employee's choice to stay or leave the organization (McPherson, 1976). Involuntary turnover focuses on firing employees with low performance (Price, 1989).It is also called functional turnover (Watrous et al., 2006).Around two decades ago, turnover has been the purpose of broad analysis. According to Mobley (1977) turnover in an organization is a time specific event noticeable by Physical separation from organization. Turnover is a behavior which is easily measureable by motivating implications (Price, 1977). Steers and Porters (1973) predicted that turnover is a serious work which seriously impact individuals and organizations. Intent to leave and thinking of quitting are the worker's intention to leave an organization. Across industries, the strong predictor of personnel turnover is behavioral intention (Gregory et al., 2007).

Intentionally or Voluntary turnover incurs both direct costs and indirect cost. The direct cost includes substitute, staffing and selection, impermanent staff and not direct costs morale, pressure on left behind staff, costs of knowledge, product \& service quality, organizational remembrance and the loss of social resources (Shaw and Dess, 2001). During downsizing direct and indirect costs contain individuality of involuntary turnover but usually it is voluntary turnover. However, financial costs are not the only result of turnover. Organizations must also moderate the effects of turnover on customer relations, trouble of efficiency; reduce in morale (Abbasi and Hollman, 2000) and the resulting effect on organizational performance 
(Watrous et al., 2006).

A manager plays an important role in reducing employee intention to leave an organization. Emotional support from supervisors \& self-respect mediated the impact of stressors on job satisfaction, stress reactions, commitment to the organization \& intent to quit. It is recommended that to improve intention to quit in turn trim down turnover, managers should keenly observe the supervisors \& subordinates relationship and work load to reduce and manage stress. In this study, we explore impacts of some main factors of turnover intentions in many organizations. The goal of this study is to observe the relationship between job commitment, job satisfaction, job stress and organizational commitment headed for turnover intention. The main purpose of this study is to search out the answers of following questions.

1. What is the relationship between job satisfaction and turnover intention?

2. What type of impact organizational commitment, job commitment and job stress has on job satisfaction?

3. How job commitment, organizational commitment, and job stress is related with turnover intention of employees

\section{Literature Review}

\section{Turnover intention}

Employee turnover is that in which employee leaving and entering in the organization. It is a most studied phenomenon. This is worth mentioning for the reason that it is in general the circumstance where people decide to leave the organization. According to shim (2010) turnover can be categories as unavoidable turnover, desirable turnover and undesirable turnover. For almost 90 years, turnover has been an essential research topic (Tse and Lam, 2008; Cotton and Tuttle, 1986), and according to scholars research it causes negative consequences for the organization. (Watrous et al., 2006; Hollman and Abbasi, 2000). Turnover intention bears a cost in which direct and indirect cost are included. . Hollman and Abbasi (2000) projected that the hidden and vision costs of turnover were $\$ 11$ billion yearly in the organization.

\section{Job satisfaction}

Job satisfaction is the status in which a person is satisfied and glad with the job. According to Oldham \& Hackman (1975) it is also the effective experience. It is the positive attitudes about one's job; conclude from his or her judgments about various aspects of work (Organ and Bateman, 1991; Locke, 1976). In global context, job satisfaction is the feeling of an employee about the job. Generally it also satisfied with particular feature, such as compensate, administration, confidence and chance for progress (Kangas et al., 1999; McNeese-Smith, 1997). It is the point of a person satisfaction and feelings towards the present job activities, responsibilities and achievements and all aspects related with the present job (Chang and Chang, 2007). According to many researchers job satisfaction is an important determinant of 
turnover intention.

The organization as an employer, the level of supervision received, financial reward, career opportunities, the nature of the work itself and fringe benefits colleagues are the different feature of job satisfaction (Warr, 2002). The attitude of employee overall acceptance, pleasure, and happiness in their work can be measured by job satisfaction. Job satisfaction is a widespread approach in which the employee focus has towards their job. It's linked directly with the person requirements including unbiased rewards, demanding work and cheering job surroundings and peers (Ostroff, 1992).

The link of turnover and job satisfaction was the most investigated topics in the previous literature of turnover. A lot of studies show an established and negative link between job satisfaction and turnover intention (Arnold et al, 1982).Koh and Goh (1995) shows negative link between turnover and job satisfaction in Singapore. Lam et al., (1995) and Aryee et al (1991) also show negative relationship. Past researches recommend a stable negative relationship between job satisfactions and turnover intention (Boal \& Blau, 1989).

H1: There is a significant relationship between job satisfaction and turnover intention.

\section{Organizational Commitment}

Organizational commitment is important variable toward turnover intention .Organizational commitment is the identification of an organization. It is directly related to employee involvement and purpose to stay in the firm and job performance (Zajac and Mathieu, 1990). It is the expressive response to a positive evaluation of the work surroundings (Testa, 2001).An emotional response may be an attachment, mostly when the individual believes strongly in the organization's standards and objective or show a strong desire to maintain membership in the organization (Scholarios and Marks, 2004). It is the commitment to the entire organization (Morrow, 1993) and support for the employee by the organization (Whitener, 2001; Zaitman-Speiser, 2005). Basically Organization commitment is the connection of emotion to an organization. Organization commitment has three major factors in the person attitudes towards the organization. These three factors are Identification, loyalty and involvement. Identification is the organization's values and goals, Loyalty is the relationship of belonging of employee and organization and at last Involvement is an activity in which employee performs a role of his job (Buchanan, 1974).

Three components of organizational commitment are affective, normative and continuance commitment (Allen and Meyer, 1991). Japanese employees found that organizational commitment could be a globally construct that applied in Japan. White et al., (1995) shows that the organizational commitment feedback form is an effective tool for measuring commitment to the organization. Susskind et al, (2000), Lin \& Chen and Van Breukelen et al, (2004) verify the important role of organizational commitment in the turnover process and show that turnover is negatively related to organizational commitment.

In explaining turnover, Porter et al study shows the importance of commitment toward 
organization. In their study, they established that organizational commitment was a good predicator of turnover than job satisfaction. In turnover literature organizational commitment has been habitually explored and show negative relation with turnover (Porter et. al, 1974). A study in Singapore on professional accountants and a longitudinal study in Hong Kong also determined a negative relationship between organizational commitment and turnover intention (Aryee et al., 1991; Wong et al. 1996). Some other researchers (Tett \& Meyer, 1993; Arnold \& Feldman, 1982; Kim et al, 1996; Ben-Bakr et al., 1994) have also projected organizational commitment an important predictor of turnover. There is a positive relationship between job satisfaction organizational commitment and (Blau, 1987).This relationship is supported many studies which identify that organizational commitment has positive relationship with job satisfaction (Tett and Meyer, 1993: Lin and Ma, 2004).

$\mathrm{H} 2$ : There is a significant relationship between organizational commitment and job satisfaction.

H3: There is a significant relationship between organizational commitment and turnover intention

\section{Job stress}

The word stress derives from the field of physics and was move into psychology. Fundamentally, the thought is that human beings have a tendency to stand firm against outside forces which are acting upon them, such as material resources and bodies (Hobfull, 1989). Now a day the perception of stress is common and contentious, and it is distinct number of ways (Keinan, 1997). There are three types of stress stimulation, stress relation and stress reaction. Stress reaction is a reaction to particular event. Stress stimulation is an enormously powerful stimulation which joins characteristics of threat and loses. Stress as relation contains characteristics of both stress as stimulation and stress as reaction. Stress is the interaction between the environment and the person.

Montgomery et al., (1996) defined job stress that the knowledge and feeling of employee about his work surroundings and the emotional and physiological reactions of employee. Job stress has received important attention in past researches (Choo, 1987; Bernard, 1997; Patten, 1995; Fisher, 2001). It is the confront for the manager because results of stress increased in absence, collection to other employee problem (Meneze 2005).Individual emotional, physical, behavioral and cognitive aspects are affected job stress. Due to job stress productivity, efficiency is affected at workplace. Job stress increases turnover.

H4: There is a significant relationship between job stress and job satisfaction.

H5: There is a significant relationship between job stress and turnover intention.

\section{Job commitment}

Job commitment is the employee willingness to look for another position that provides more 


\section{Macrothink}

constructive conditions then the present job. This is constant with the model of turnover proposed by price in 1977. Job commitment is sign of intention to leave (Muller and Price, 1981). In another study Koch and steers (1978) that job commitment is a component of intention to leave. Mobely (1977) propose that job commitment is a sign of decision to leave the organization. Job commitment is a wide continuum of attitudes concerned with the loyalty to a job and organization. . The relationship of job commitment with job satisfaction and intention to leave has been found to succeed in many occupations. In management information system personal, the most important determinants of turnover were lack of job satisfaction and commitment of job (Igbaria and Greenhaus; 1992).

H6: There is a significant relationship between job commitment and job satisfaction.

$\mathrm{H7}$ : There is a significant relationship between job commitment and turnover intention.

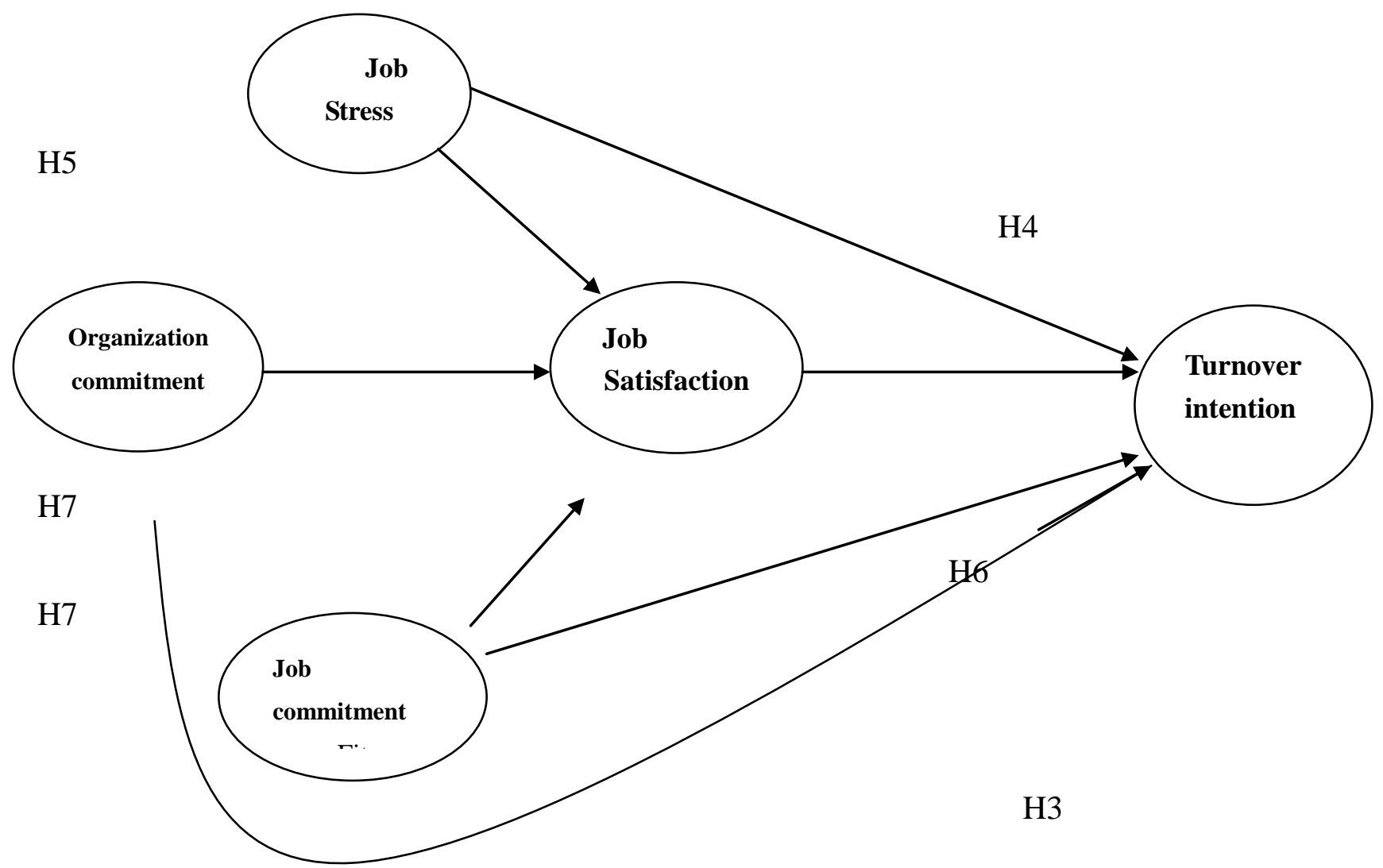

Figure 1

Purposed Model 


\section{1) Macrothink}

\section{Methodology}

\section{Sample and procedure}

A sample is consisted of 150 employees in whom 92 (61.7\%) were male and $57(38.3 \%)$ female. The self administrated questioners were used to collect data. In the processing of data we check separate findings of each variable. Table 1 represents the sample information regarding gender age, salary and education. The majority of respondents were male between the ages of 30 to 40 years. The maximum educations of respondents were masters (55\%). The questioners were filled by employees of different organizations. In this study we used convenient sampling to collect data.

Table 1: Sample Profile

\begin{tabular}{|c|c|c|}
\hline Characteristics & frequencies & percent \\
\hline \multicolumn{3}{|l|}{ Gender } \\
\hline Male & 92 & 61.7 \\
\hline Female & 57 & 38.3 \\
\hline \multicolumn{3}{|l|}{ Age } \\
\hline $20-30$ years & 43 & 28.9 \\
\hline $30-40$ Years & 73 & 49.0 \\
\hline 40-50 Years & 13 & 8.7 \\
\hline $50-60$ years & 13 & 8.7 \\
\hline Above 60 years & 7 & 4.8 \\
\hline \multicolumn{3}{|l|}{ Salary (Rs/month) } \\
\hline Below 15000 & 29 & 19.5 \\
\hline $15000-25000$ & 38 & 25.5 \\
\hline $25000-35000$ & 23 & 15.4 \\
\hline $35000-45000$ & 32 & 21.5 \\
\hline $45000-55000$ & 25 & 16.8 \\
\hline Above 55000 & 2 & 1.3 \\
\hline \multicolumn{3}{|l|}{ Education } \\
\hline Matriculation & 9 & 6.0 \\
\hline Inter & 16 & 10.5 \\
\hline Bachelor & 23 & 15.7 \\
\hline Master & 55 & 36.9 \\
\hline MS/M. Phil & 38 & 25.5 \\
\hline PHD & 8 & 5.4 \\
\hline
\end{tabular}

\section{Instrument}

The research tool is self administrative questioner consisted of five variables with 26 items. Each item is measured five item likert response scale ranging from one "strongly agree" to five "strongly disagree". Each item was discussed one by one. The value of Cronbach's a given in table 2. Cronbach's alpha is used to measure the internal consistency of these items. The four items of turnover intention scale developed by (Seashore et al., 1982) were used to 
measure the turnover intention among employees. A sample item was: "You will not give up this company easily". We used the survey questionnaire with a five-point Likert scale ranging from 1 "strongly agree" to 5 "strongly disagree". The Cronbach's a of five items scale was 0.747 .

The five-item Organizational Commitment scale developed by Mowday et al. (1979) was used to measure Organizational Commitment among employees (e.g. I would accept almost any type of job assignment in order to keep working for this organization). Respondents rated the statements on a five-point scale, ranging from strongly agree to strongly disagree. The Cronbach's of five item scale was 0.837 .

Job Satisfaction was measured via five items rated on a five-point scale ranging from strongly agrees to strongly disagree (e.g. My current work situation is not a great source of frustration in my life).The scale was developed by Konrad et al. (1999). The Cronbach's a of five item scale was 0.799

Scale developed by Tate et al. (1997) was used to measure the overall job stress of employees. Job stress was measured by mental stress symptoms and physical stress symptoms. Three items were used to measure the mental stress (e.g. I feel frustrated at my job) and five item were used to measure the physical symptoms of stress (e.g., I lose my appetite because of my job related problems). Participants indicated on a five-point likert scale the degree of their agreement regarding each of these symptoms. The Cronbach's a of eight items scale was 0.869

Job commitment scale developed by Meyer and Allen, (1991).The scale contain four items to measure job commitment (e.g. I feel like part of the family at my organization).The Cronbach's a of five items likert scale was 0.835.The instrument is given in Appendix 1

\section{Reliability Test}

\begin{tabular}{|l|l|l|}
\hline Variable & Items & Cronbach's a \\
\hline Turnover intention & 4 & 0.747 \\
\hline Job stress & 8 & 0.869 \\
\hline Organizational commitment & 5 & 0.837 \\
\hline Job commitment & 5 & 0.799 \\
\hline Job satisfaction & 4 & 0.835 \\
\hline
\end{tabular}

Table 2: Results of Reliability Test 


\section{Data Analysis}

Data were analyzed using SPSS software version 19.0.The value of $\mathrm{R}^{2}$ shows the influence of depended variable due to the independed variables. In the first model in which turnover intention as depended variable the value of $\mathrm{R}^{2}$ is 0.492 which represent that $49 \%$ change in the model .In the $2^{\text {nd }}$ model in which job satisfaction treated as depended variable. The value of $\mathrm{R}^{2}$ is 0.577 which indicates that $57 \%$ change in the model due to the job satisfaction.

The regression analysis was used to test the hypothesis. Beta coefficient basically measures the variance of in depended variable caused by depended variable in the model. The $p$ value shows the significant level of models. To examine the hypothesis H1which is the link between job satisfaction and turnover intention. The values of $(\beta=-.200$ and $p<.030)$ which represent that there is a negative relationship between job satisfaction and turnover intention. The $20 \%$ change in job satisfaction also affects the turnover intention. Because of these $\mathrm{H} 1$ is accepted. The relationship between organizational commitment and job satisfaction $(\beta=0.224$ and $\mathrm{p}<.040$ ) is highly significant . The $22 \%$ change in organization commitment effect turnover intention. The relationship between organization commitment and turnover intention $(\beta=-0.145$ and $p<.001)$ shows negative relationship and $14 \%$ change in organization commitment effects job satisfaction. Because of these results $\mathrm{H} 2$ and $\mathrm{H} 3$ are accepted.

The relationship between job stress and turnover intention $(\beta=-0.296$ and $\mathrm{p}<0.00)$ is positive and $29 \%$ change in job stress effects turnover intention. The relationship between job stress job satisfaction $(\beta=-.286$ and $p<0.00)$ showed negative relationship. The result shows that $28 \%$ change in job satisfaction is due to job stress. Because of these results the hypothesis $\mathrm{H} 4$ and $\mathrm{H} 5$ are accepted. The relationship between job commitment and turnover intention $(\beta=-.247$ and $p<.030)$ is negative and $24 \%$ change in turnover intention due to job commitment .The relationship between job commitment and job satisfaction $(\beta=0.453$ and $\mathrm{p}<.000$ ) shows positive relationship. The result shows that $45 \%$ change in job satisfaction is due to the job commitment. Because of these results the hypothesis H6 and H7 are accepted. 


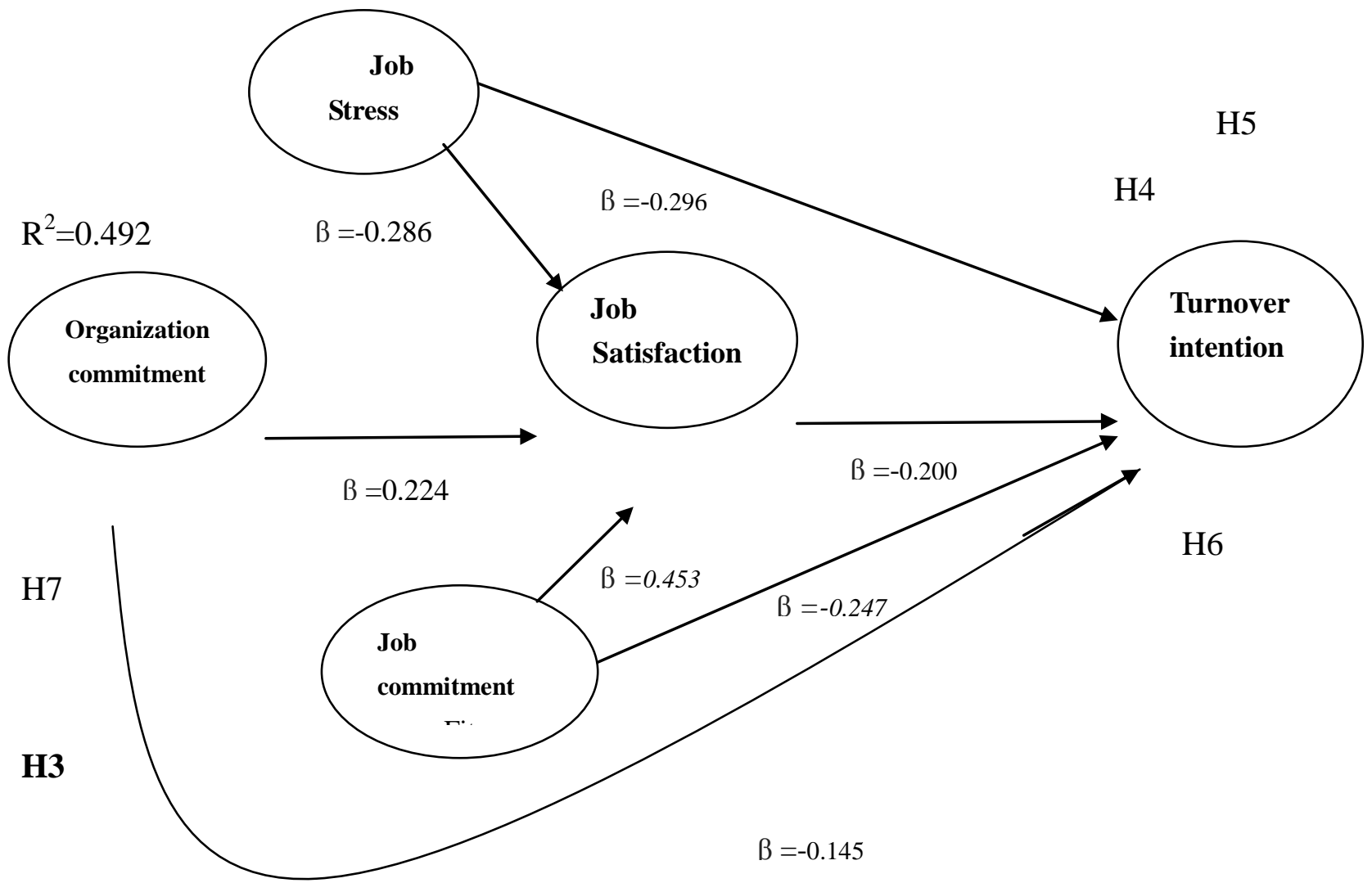

Figure 2

Final Model Results

\section{Regression Results}

\begin{tabular}{|l|l|l|l|l|l|l|}
\hline Relationships & Variables & Std.error & Beta & \multicolumn{1}{|c|}{ t } & Sig & Result \\
\hline H1 & $\begin{array}{l}\text { J.S } \\
\text { t.i }\end{array}$ & .184 & -0.200 & -2.197 & .030 & Supported \\
\hline H2 & $\begin{array}{l}\text { o.c } \\
\text { j.s }\end{array}$ & .058 & 0.224 & 3.506 & .001 & Supported \\
\hline H3 & $\begin{array}{l}\text { o.c } \\
\text { t.i }\end{array}$ & .078 & -0.145 & -1.989 & .040 & Supported \\
\hline
\end{tabular}




\begin{tabular}{|l|l|l|l|l|l|l|}
\hline H4 & $\begin{array}{l}\text { j.s } \\
\text { j.st }\end{array}$ & .054 & -0.286 & -4.750 & .000 & Supported \\
\hline H5 & $\begin{array}{l}\text { j.s } \\
\text { t.i }\end{array}$ & .075 & -0.296 & 4.178 & .000 & Supported \\
\hline H6 & $\begin{array}{l}\text { j.c } \\
\text { j.s }\end{array}$ & .056 & 0.453 & 7.204 & .000 & Supported \\
\hline H7 & $\begin{array}{l}\text { j.c } \\
\text { t.i }\end{array}$ & .083 & -0.247 & -3.079 & .002 & Supported \\
\hline
\end{tabular}

Table 3: Regression Results

\section{Results and Discussions}

The SPSS program is used to analyze the data and to examine study hypothesis. The test used is the regression and correlation analysis. Table 1 represents the description of study sample From the table 1 we can see that that 61 percent respondents were male and 38 percent were female. In education sector 9 persons hold a degree of metric ,10 percent held intermediate degree ,15 percent held bachelor degree ,36 percent held masters degree ,25 percent held MS and Mphil degree and 5 percent held $\mathrm{PhD}$ degree The majority of the participants were (49\%) were between 30 and 40 years old, 28 percent from 20 and 30 years old, 8 percent from both 40 to 50 and 50 to 60 years of age and 4 percent from above 60 years of age. The majority of participants were salary range from $15000-25000$ which were 25 percent, 19 percent from a salary range of below 15000, 15 percent from 25000-35000, 21 percent from $35000-45000,16$ percent from $45000-55000$ and 1 percent from above 55000 of salary range.

The purpose of this study was to explore the relationship between job satisfaction and turnover intention and other variables which are related to them. In this study firstly we see the relationship between job satisfaction and turnover intention. There is negative relationship between job satisfaction and turnover intention. Results of many studies have provided proof of a strong negative relationship between job satisfaction and turnover intentions (Mannheim et al., 1997; Abraham, 1999). A significant body of literature, and on the whole the early research, has underlined the possible effects of job satisfaction on employee turnover (Muchinsky et al., 1979).

Secondly we examined the relationship of organizational commitment, job stress and job commitment with the job satisfaction. Job commitment is an important variable which influence job satisfaction and $45 \%$ change in job commitment influence job satisfaction. Job stress is negatively related to the job satisfaction. Williams et al., (2001), showed the fundamental relationship between job satisfaction and job stress has been assumed and 
empirically tested (Lee and Ashforth, 1993). The meta-analysis was applied to test the hypothesis (Sullivan and Bhagat, 1992). The logical results confirm the concept that job stress is negatively related to job satisfaction. The behavioral outcomes of these are job commitment toward organization, job dissatisfaction are a greater tendency to leave the organization (Barsky et al., 2004; Cummins, 1989). Organizational commitment is positively related to job satisfaction

Now we discussed the third question in which the linkage of job stress, job commitment and organizational commitment with turnover intention. The relationship between job stress and turnover intention is negative. According to Kahn and Byosiere, 1992; Koslowsky, 1998, Job stress incentives begins in the job itself and have negative impact .In our study we prove that the negative relation $\beta=-0.296$ between job stress and turnover intention. In this research we also examine the relationship between organizational commitments and turnover intention. The results of previous studies shows negative relation between commitment and turnover intention (Deconinc Bachmann ,1994;Tett Meyer ,1993;Allen and Mayer ,1990 ;Good et al.,1988;Dougherty et al .,1985). The literature shows that strongly committed employees are those who are least likely to leave the organization. Results also shows negative relation $\beta=$ -0.145 between commitment and turnover intention. More recently, an increasing number of studies have sought to include the concept of organization commitment as a predictor of employee attitudes and behavior (Glisson, et al., 1988). But, very few studies have thoroughly and at the same time examined "satisfaction" and the degree of individual commitment to the organization. At last we discussed the relationship between job commitment and turnover intention. Result shows the negative $\beta=-.247$ relation between job commitment and turnover. Glisson, et al., (1988) shows that job commitment was a broader concept which is different from organizational commitment. If degree of freedom is $5 \%$ then results of beta for $\mathrm{H} 1 \mathrm{H} 2 \mathrm{H} 3 \mathrm{H} 4 \mathrm{H} 5 \mathrm{H} 6 \mathrm{H} 7$ are significant and hypothesis is accepted. If it is more or less then see the column Sig. if values are greater than the degree of freedom then results are insignificant and hypothesis will be rejected, if values are smaller than the degree of freedom then results will be significant and hypothesis will be accepted.

\section{Conclusion}

This research is successfully conducted. Turnover intention is largely influenced by the job satisfaction, job commitment, organizational commitment and job stress. However, for managers who are concerned about the impact intention to quit and possible turnover, these variables are factors over which they may have some control. The human resource department should plan and implement the strategies to retention of employees in the organization. The HR manager should design different retention strategies of employees. These strategies a combination of organizational mission, goals and objective, establish cooperate culture and communication, work surroundings and job design, appoint and promotions, training, worker acknowledgment, rewards \& payment, worker feat, appraisal and growth, and leadership.

\section{Limitations}

The research has several limitations. First is the fact that we used biased sample which is due 
to small sample size. Second limitation of this study was convenient sampling. Third limitation of this study is global economic condition which influence economies and it also impact on intention to quit. The limitations of time and resource constrains has faced in this study.

\section{Recommendation}

For further research we can examine the moderating role of other variables which influence turnover intention. This study can also organize at different organizational levels i.e. top, middle and line manager. Advancement opportunity, mystery goals approach, job performance, and personality of employees can also be considered for further research.

\section{References}

1.Aremu, O, A., adeyoju, A, C., (2003).job commitment, job satisfaction and gender as predictors of mentoring in Nigeria police An international journal of police strategies \&management vol 26 no 3 pp 377-385

2. Anitha, R.D., (2011). A STUDY ON JOB SATISFACTION OF PAPER MILL EMPLOYEES WITH SPECIAL REFERENCE TO UDUMALPET AND PALANI TALUK. Journal of management and science, Vol. 1, No.1, Sep 2011, pp. 36-47.

3. Bhagat, S. R, Krishnan, B., Nelson, A. T., Leonard. K., Jr, F.L.D., Billing, K.T., (2010),"Organizational stress, psychological strain, and work outcomes in six national contexts: A closer look at the moderating influences of coping styles and decision latitude", Cross Cultural Management: An International Journal, Vol. 17 Iss: 1 pp. 10 - 29

4. Chen, C.J., Silverthorne, C., Hung, Y.J., (2006),"Organization communication, job stress, Organizational commitment, and job performance of accounting professionals in Taiwan and America", Leadership \& Organization Development Journal, Vol. 27 Iss: 4 pp. $242-249$

5. Chen, J., Colin, C., (2008). The impact of locus of control on job stress, job performance and job satisfaction in Taiwan, Leadership \& Organization Development Journal. Vol. 29 No. 7, 2008 pp. 572-582

6. Chiu, K.C., Chien, S.C., Lin, P., Hsiao, Y.C., (2005),"Understanding hospital employee job stress and turnover intentions in a practical setting: The moderating role of locus of control", Journal of Management Development, Vol. 24 Iss: 10 pp. 837 - 855

7. Dysvik, A., Kuvaas, B., (2010),"Exploring the relative and combined influence of mastery-approach Goals and work intrinsic motivation on employee turnover intention", Personnel Review, Vol. 39 Iss: 5 pp. $622-638$

8. Eddleston, A.M, A.M., (2009),"The effects of social comparisons on managerial career satisfaction and

Turnover intentions", Career Development International, Vol. 14 Iss: 1 pp. 87 - 110 
9. Freund, A., Carmeli A., (2003). An empirical assessment: reconstructed model for five universal forms of work commitment, journal of managerial psychology vol 18 no $7 \mathrm{pp}$ 708-725

10. Fairbrother,K., Warn,J., ( 2003)workplace dimensions ,stress and job satisfaction Journal of Managerial Psychology Vol. 18 No. 1, pp. 8-21

11. Falkenburg, K., Schyns, B., (2007),"Work satisfaction, organizational commitment and withdrawal behaviors", Management Research News, Vol. 30 Iss: 10 pp. 708 - 723.

12. Firth, L., Mellor, J.D., Moore, A.K., Loquet, C., (2004),"How can managers reduce employee Intention to quit?” Journal of Managerial Psychology, Vol. 19 Iss: 2 pp. 170 - 187

13.Gunlu, E., Nilu, A.M., Percin A.S.F., (2010). Job satisfaction and organizational commitment of hotel managers in Turkey. International Journal of Contemporary Hospitality Management Vol. 22 No. 5, pp. 693-717

14. Gumbang, B., Suki, M.N., Suki, M.N., (2010). DIFFERENCES BETWEEN JOB SATISFACTION, ORGANISATIONAL COMMITMENT AND GENDER. Labuan e-Journal of Muamalat and Society. Labuan e-Journal of Muamalat and Society, Vol. 4, 2010, pp. 1-13

15.Halepota, A.J., Shah, N., (2011),"An empirical investigation of organizational antecedents on employee job satisfaction in a developing country", Transforming Government: People, Process and Policy, Vol. 5 Iss: 3 pp. 280 - 294

16. Halloran, O.L.P., (2012),"Performance pay and employee turnover", Journal of Economic Studies, Vol. 39 Iss: 6 pp. $653-674$

17. Jordan, J.P., Troth, A., (2011),"Emotional intelligence and leader member exchange: The relationship with employee turnover intentions and job satisfaction", Leadership \& Organization Development Journal, Vol. 32 Iss: 3 pp. 260 -280

18. Jawahar, I.M., Hemmasi, P., (2006),"Perceived organizational support for women's advancement and turnover Intentions: The mediating role of job and employer satisfaction", Women In Management Review, Vol. 21 Iss: 8 pp. 643 - 661

19. KHATRI, N., BUDHWAR, P., EMPLOYEE TURNOVER: BAD ATTITUDE OR POOR MANAGEMENT?

20. Kuean,L.W., Kaur .S.,Wong K.S.E., (2010).the relationship between organizational commitment and intention to quit .journal of applied sciences .19(10).pp 2250-2260 .

21 .Kiyak, A.H., Namazi, H. K., Kahana F.E.,( 1997).job commitment and turnover among women workers in facilities serving older person .vol 19 , no .2 pp.223-246.

22. Koh.C.H. Boo, H.Y.F.E., (2004). Organizational ethics and employee satisfaction and commitment Management Decision Vol. 42 No. 5, 2004 pp. 677-69.

23. Kelley, L.L., Blackman, A.D., Hurst, P.J., (2007),"An exploration of the relationship between learning organizations and the retention of knowledge workers", The Learning 
Organization, Vol. 14 Iss: 3 pp. $204-22$.

24. Karakus „M., Aslan B., (2009) .Teachers' commitment focuses: a three-dimensioned view Journal of Management Development Vol. 28 No. 5, 2009 pp. 425-438.

25. Min, H., (2007),"Examining sources of warehouse employee turnover", International Journal of Physical Distribution \& Logistics Management, Vol. 37 Iss: 5 pp. 375 - 388.

26. Morrell, M.K., Clarke, L.J., Wilkinson, J.A., (2004),"Organizational change and employee turnover", Personnel Review, Vol. 33 Iss: 2 pp. $161-173$

27. Moncarz, E., Zhao, H (2009). An exploratory study of US lodging properties' organizational practices on employee turnover and retention. International Journal of Contemporary Hospitality Management Vol. 21 No. 4, 2009 pp. 437-458

28. Michela, L.J., (2008),"Understanding employees' reactions to supervisors' influence behaviors: A community sample predicting employee commitment, turnover, and stress", International Journal of Organizational Analysis, Vol. 15 Iss: 4 pp. $322-340$.

29.Michael, O., Court, D., Petal, P., (2009),"Job stress and organizational commitment among mentoring Coordinators", International Journal of Educational Management, Vol. 23 Iss: 3 pp. $266-288$

30.Pelit, E., Öztürk, Y., Arslantürk, Y., (2011),"The effects of employee empowerment on employee job satisfaction: A study on hotels in Turkey", International Journal of Contemporary Hospitality Management, Vol. 23 Iss: 6 pp. 784 - 802

31. Paillé, P, P., Fournier, S.P., Lamontagne,S., (2011),"Relationships between commitments to the organization, the superior and the colleagues, and the intention to leave among truckers", International Journal of Organizational Analysis, Vol. 19 Iss: 2 pp. 92 - 108

32. Park, S .J. Kim, H.T., (2009),"Do types of organizational culture matter in nurse job satisfaction and turnover intention?", Leadership in Health Services, Vol. 22 Iss: 1 pp. 20 - 3

33. Ramesh, K., Charles, R., Yacob,P, P, P, P., (2012). A Study on Turnover Intention in Fast Food Industry: Employees' Fit to the Organizational Culture and the Important of their Commitment, International Journal of Academic Research in Business and Social Sciences, Vol. 2, No. 5 pp 10-42.

34. Silverthorne, C., (2004),"The impact of organizational culture and person-organization fit on organizational commitment and job satisfaction in Taiwan", Leadership \& Organization Development Journal, Vol. 25 Iss: 7 pp. 592- 599

35. Sawyerr, O.O., Srinivas, S., Wang, S., (2009),"Call center employee personality factors and service performance", Journal of Services Marketing, Vol. 23 Iss: 5 pp. $301-317$

36.Suliman, M.A., Obaidli, A.H, A.H., (2011),"Organizational climate and turnover in Islamic banking in the UAE", International Journal of Islamic and Middle Eastern Finance and Management, Vol. 4 Iss: 4 pp. $308-324$ 


\section{Macrothink}

Journal of Public Administration and Governance ISSN 2161-7104 2014, Vol. 4, No. 3

37. Tella, A., Ayeni, C.O., Popoola, O.S., (2007). Work Motivation, Job Satisfaction, and Organizational Commitment of Library Personnel in Academic and Research Libraries in Oyo State, Nigeria.

38. Wells, E.J., Peachey, W.J., (2011),"Turnover intentions: Do leadership behaviors and satisfaction with the leader matter?" Team Performance Management, Vol. 17 Iss: 1 pp. 23 40

39.Wang, L.G., Lee, J.Y., Ho C.C., (2012). The Effects of Job Satisfaction, Organizational Commitment and Turnover intention on Organizational operating performance: as Exemplified with Employees of Listed Property Insurance Companies in Taiwan. Research in Business and Management Vol.1 (2), pp.41-53,

40. Weisberg, J., (1994). Measuring Workers' Burnout and Intention to Leave", International Journal of Manpower, Vol. 15 Iss: 1 pp. $4-14$

41. Yousef A, D., (2002). Job satisfaction as a mediator of the relationships between role stressors and organizational commitment journal of managerial psychology vol 17 No 4 pp. 250-266.

42.Yang,J., Gong,Y., Huo,Y., (2011),"Proactive personality, social capital, helping, and turnover intentions", Journal of Managerial Psychology, Vol. 26 Iss: 8 pp. 739 - 760

43. Zaffane, M, R., (1994),"Understanding Employee Turnover: The Need for a Contingency Approach",International Journal of Manpower, Vol. 15 Iss: 9 pp. 22 - 37

44. Zimmerman, D.R., Darnold, C.T., (2009),"The impact of job performance on employee turnover intentions and the voluntary turnover process: A meta-analysis and path model", Personnel Review, Vol. 38 Iss: 2 pp. $142-158$ 


\section{Appendix}

\begin{tabular}{|c|c|c|c|}
\hline No. & Variable & Items & Source \\
\hline 1 & $\begin{array}{l}\text { Turnover } \\
\text { Intention }\end{array}$ & $\begin{array}{l}\text { 1.You are very likely to stay in this company for the next five } \\
\text { years } \\
\text { 2.For you, this company is the best of all possible organizations } \\
\text { to work for } \\
\text { 3.You will not give up this company easily } \\
\text { 4.You seldom hear about or are exposed to jobs outside your } \\
\text { company that interest you }\end{array}$ & $\begin{array}{l}\text { (Seashore et } \\
\text { al., 1982) }\end{array}$ \\
\hline 2 & $\begin{array}{l}\text { Organizational } \\
\text { Commitment }\end{array}$ & $\begin{array}{l}\text { 1. I would accept almost any type of job assignment in order to } \\
\text { keep working for this organization } \\
\text { 2. I feel very little loyalty to this organizational } \\
\text { 3. I am proud to tell others that I am part of this organization } \\
\text { 4. I talk up this organization to my friends as a great } \\
\text { organization to work for } \\
\text { 5. It would take very little chance in my present circumstances } \\
\text { to cause me to leave }\end{array}$ & $\begin{array}{l}\text { Mowday et } \\
\text { al. (1979) }\end{array}$ \\
\hline 3 & $\begin{array}{l}\text { Job } \\
\text { Satisfaction }\end{array}$ & $\begin{array}{l}\text { 1. Overall, I am pleased with my work } \\
\text { 2.Overall, I am satisfied in my current practice } \\
\text { 3. My current work situation is a major source of frustration in } \\
\text { my lifea } \\
\text { 4. My work in this practice has not met my expectations } \\
\text { 5. If I had it to do it all over again, I'd still choose to work } \\
\text { where I do now }\end{array}$ & $\begin{array}{l}\text { Konrad et al. } \\
\text { (1999) }\end{array}$ \\
\hline 4 & Job Stress & $\begin{array}{l}\text { 1. I feel emotionally drained by my job } \\
2 \text {.I feel burned-out by my job } \\
\text { 3. I feel frustrated at my job }\end{array}$ & $\begin{array}{l}\text { Tate et al. } \\
(1997)\end{array}$ \\
\hline
\end{tabular}




\begin{tabular}{|l|l|l|l|}
\hline & & $\begin{array}{l}\text { 4. I feel tense at my job } \\
\text { 5. I lose my appetite because of my job related problems } \\
\text { 6. Job related problems make e awake at night } \\
\text { 7. Job related problems make my stomach upset } \\
\text { 8. Job related problems make my heart beat faster than usual }\end{array}$ & \\
\hline 5 & $\begin{array}{l}\text { Job } \\
\text { commitment }\end{array}$ & $\begin{array}{l}\text { 2. I feel like "part of the family" at the organization. } \\
\text { for me. } \\
\text { 3. I feel "emotionally attached" to the organization. } \\
\text { 4. I feel a strong sense of belonging to the organization. }\end{array}$ & $\begin{array}{l}\text { Meyer and } \\
\text { allen, (1991) }\end{array}$ \\
\hline
\end{tabular}

